\title{
The Influence of Self-Cleaning Processes on the Quality of Drinking Water of Stryi Water Intake Wells
}

\author{
Volodymyr Snitynskyi ${ }^{1}$, Petro Khirivskyi ${ }^{1}$, Volodymyr Cherniuk ${ }^{2,3}$, \\ Ihor Hnativ ${ }^{1 *}$, Roman Hnativ ${ }^{2}$, Orest Verbovskiy ${ }^{2}$, Irina Bihun ${ }^{2}$ \\ 1 Department of Ecology, Lviv National Agrarian University, Volodymyra Velykoho str., 1, Dublyany, Lviv region, \\ 30831, Ukraine \\ 2 Institute of Civil Engineering and Building Systems, Lviv Polytechnic National University, Karpinsky str., 6, \\ Lviv, 79013, Ukraine \\ 3 John Paul II Catholic University of Lublin, Aleje Racławickie 14, 20-950 Lublin, Poland \\ * Corresponding author's e-mail: gnativ.roman.m@gmail.com
}

\begin{abstract}
In order to solve the problem of providing the population with high-quality drinking water, preference is given to the use of groundwater deposits, which differ from surface sources in better quality and are more protected from man-made influences and climate change. Thirty-seven existing groundwater deposits are used for drinking and technical water supply in Lviv region. The distribution of groundwater in the region is very uneven, and in the Eastern Carpathians they are almost non-existent. The main factors of groundwater pollution in most of Ukraine are municipal sewage, livestock effluents, unorganized warehouses for storage of industrial waste, fertilizers and pesticides and other local objects that affect the state of groundwater. The gradual reduction of mineral fertilizer and pesticide usage has led to some improvement in the quality of groundwater, but for some agro-industrial areas the presence of residual pesticides and nitrogen compounds in groundwater remains a relevant problem. This year, there was an increase in the use of mineral fertilizers compared to last year. The aim of this work was to study the compliance of the maximum allowable concentrations of hydrochemical parameters of the wells of the Stryi water intake and to determine the potential impact of anthropogenic factors on water quality. The compliance with the sanitary and hygienic requirements of the hydrochemical parameters of water in the wells of the Stryi water intake was analyzed. The regularities of their changes as well as the presence of wells that have a potentially unstable chemical composition and are prone to deterioration of water quality were determined. The results of studies of related to the impact of self-treatment processes in the river Stryi on the quality of water intake in the city of Stryi showed that the drinking water from artesian wells is of high quality and now there are no negative effects of river water in the Stryi basin on groundwater deposits. The quality of river water is satisfactory for its use in domestic and drinking water supply and for recreational purposes.
\end{abstract}

Keywords: mountain rivers, surface runoff, groundwater, natural self-purification processes, drinking water quality, man-made impacts.

\section{INTRODUCTION}

Water is the most important of the natural resources used for industrial and agricultural production, and in terms of use, it far exceeds all other necessary resources. The problem of satisfactory living conditions is relevant for both industrialized and recreational areas, which include all settlements in the Carpathian region. One of the most important indicators of the state of the environment is the quality of drinking water [Didula et al., 2018].

In Ukraine, an uneven distribution of drinking water by region is observed. In the Zaporizhia, Donetsk, Kherson, Mykolaiv and Odessa regions, there is only 10 to 40 thousand $\mathrm{m}^{3}$ of water per $1 \mathrm{~km}^{2}$ of land, taking into account underground sources. This is from 120 to $400 \mathrm{~m}^{3}$ per capita, 
i.e.15-20 times less than in the western regions [Prokopov et al., 2011].

The content of various chemical elements in drinking water depends on natural and anthropogenic factors. Natural influences are due to the primary content of these elements in open water, groundwater and soil, and anthropogenic ones cause the entry into the environment of chemical elements due to human economic activity [Prodanchuk et al., 2006]. Pollution of natural reservoirs with substances of man-made origin complicates the use of water for drinking purposes. In the Lviv region, from 1995 to 2012, water consumption for domestic and drinking needs decreased by 3.14 times, and for industrial needs by 2.54 times. Most of the drinking water in the region is taken from underground sources. In 2010 , the total intake of water from underground sources was 250.2 million $\mathrm{m}^{3}$, including 110.7 million $\mathrm{m}^{3}$ for the city of Lviv. Moreover, 78.3 million $\mathrm{m}^{3}$ were used for domestic and drinking needs, while 46.5 million $\mathrm{m}^{3}$ for production needs. There is a risk associated with the impact of the ecological status of water in surface and groundwater sources on the quality of drinking water intake [Hnativ, 2021].

Water bodies with sewage and surface runoff from urban areas receive toxic substances, namely petroleum products, phenol, ammonia, fertilizers and plant protection products, complex chemical compounds, etc. Some harmful compounds can be stored for a very long time in surface sources and penetrate deep into groundwater.

\section{MATERIALS AND METHODS}

In order to solve the problem of providing the population with high-quality drinking water, preference is given to the use of groundwater deposits, which differ from surface sources in better quality as well as greater protection from man-made influences and climate change. Thirtyseven existing groundwater deposits are used for drinking and technical water supply in the Lviv region. The distribution of groundwater in the region is very uneven, and in the Eastern Carpathians it is almost non-existent. According to the hydrogeological zoning of Ukraine, the Lviv region is located within the Volyn-Podilsky and Precarpathian artesian basins and the mountainous region of the Carpathians. The main factors that determine the conditions of formation of water intakes are the peculiarities of the geological structure, the intensity of infiltration of precipitation and the rate of water exchange in these basins. The distribution and capacity of aquifers depends on the landscape structure of the territory. They are located in floodplains, low terraces of rivers, lake and swamp depressions, and their depth varies from 0 to $10 \mathrm{~m}$ [Ivanov, 2009].

The low quality of drinking water is not only due to the pollution of its sources, but also the lack of water protection zones around them and the unsatisfactory condition of water supply networks (Fig. 1). The environmental consequences of water consumption are related not only to the size of water intake, but also to the structure of water use. Up to $70 \%$ of water consumed is used in agriculture, mainly for irrigation. About 20\% of water is consumed by industry, and the remaining $10 \%$ of water is used for domestic and drinking needs.

According to Article 27 of the Law of Ukraine "On Drinking Water and Drinking Water Supply" the system of standards in the field of drinking water supply includes the international and state standards of Ukraine, which define: state standard for drinking water, state standard for bottled drinking water, and methods, techniques as well as tools control and assessment of drinking water quality. These standards establish a list of organoleptic, chemical, microbiological and radiological indicators of drinking water quality that require mandatory control, their maximum permissible values, compliance with which is safe for human life and health. [Hrib et al., 2015].

In recent years, the water quality of the main sources of centralized water supply has significantly deteriorated due to unsatisfactory

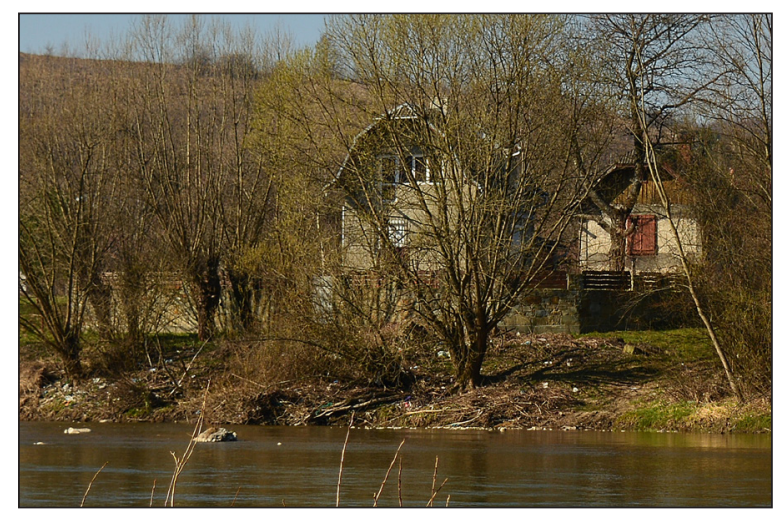

Figure 1. Location of buildings on the coastal protection strips of the Stryi River in 2020 (Mezhybrody village) 
water management, pollution of river runoff and groundwater aquifers with organic compounds, phenols, nitrates, petroleum products, pathogenic microorganisms and more. Today, according to certain physical and chemical indicators (total salt content, iron, etc.) the drinking water does not meet the requirements of the standard in 260 settlements of Ukraine.

The purpose of the paper was to study the compliance of the maximum allowable concentrations of hydrochemical parameters of the wells of the Stryi water intake and to determine the potential impact of anthropogenic factors on water quality.

To achieve this goal, the following tasks are solved:

- analyze the compliance with sanitary and hygienic requirements of hydrochemical parameters of water in the wells of the Stryi water intake and to determine the patterns of their changes;

- establish the presence of wells that have a potentially unstable chemical composition and are prone to deterioration of water quality.

\section{RESULTS AND DISCUSSION}

According to the results of monitoring studies of tap water conducted by the SE "Lviv Regional Laboratory Center of the Ministry of Health of Ukraine" in 2019, it was found that water does not meet regulatory requirements for sanitary-chemical and sanitary-microbiological indicators in the cities of Stryi, Mostyska and Khodoriv. In all cases, proposals were sent to local governments to develop a plan of measures to improve the condition of water intakes and provide financial support for the implementation of these measures. The situation with the provision of drinking water supply to the population of Turka is difficult. For many years, there has been no centralized water supply in the city, and therefore drinking water is supplied to residential buildings and public facilities from a large number of mine wells, which are problematic due to possible pollution and lack of water quality control [National report, 2020].

The main factors of groundwater pollution in most of Ukraine are municipal sewage, livestock effluents, unorganized warehouses for storage of industrial waste, fertilizers and pesticides and other local objects that affect the state of groundwater. The gradual reduction of the use of mineral fertilizers and pesticides has led to some improvement in the quality of groundwater, but for some agro-industrial areas the problem of the presence of residual pesticides and nitrogen compounds in groundwater remains relevant. This year, there was an increase in the use of mineral fertilizers compared to last year.

Manifestations of reckless use of natural resources are the growth of plowing of sloping areas and insufficient anti-erosion measures. The negative consequences of agriculture and plowing of soils in the mountainous areas of the basin increase the environmental threats of exogenous geological processes (Fig. 2). Excessive compaction of the loamy soil on the slopes of the mountains by heavy agricultural machinery and grazing of domestic animals reduces the filtration of precipitation, as well as causes an increase in rainwater runoff, leading to stagnant water in the depressions. Plowing of soils in the autumn periods of significant precipitation are the worst prerequisites for the destructive impact on the area of slopes with the formation of linear erosions and the development of deeply incised ravines [Radecki-Pawlik et al., 2018].

These factors of man-made influences, which cause linear erosion cuts on sloping watersheds, lead to the removal of thousands of tons of mineral and organic compounds annually from plowed areas in the river basin, which compensate up to $25 \%$ by applying fertilizers. The use of fertilizers and chemical plant protection products has a significant impact on the river waters of the basin, so the monitoring of farms and other agricultural enterprises is now an important issue.

With the intensive use of many mineral fertilizers, an increase in the acidity of groundwater and soil is caused, and therefore the need for

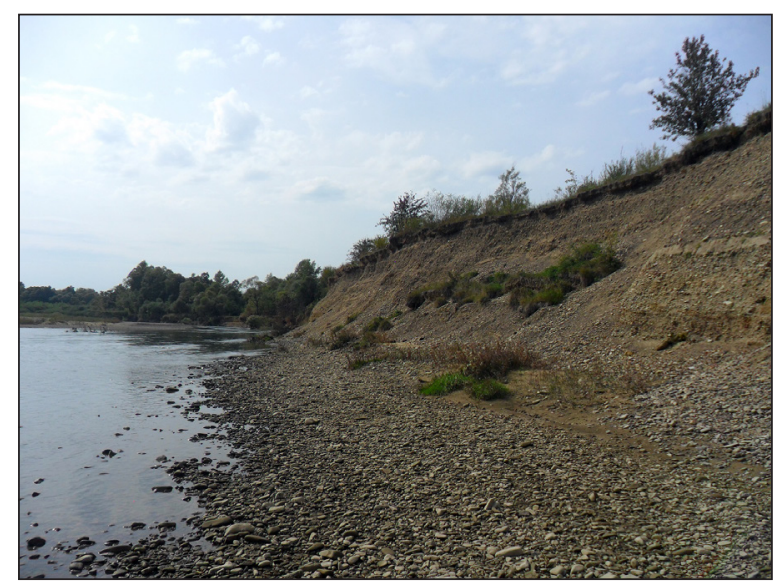

Figure 2. The river Stryi near the village of Dobryany, Stryi district 
liming soils and neutralizing the acidic effects of fertilizers increases. Mineral fertilizers also contain related ballast elements (fluorine, chlorine, sodium) and toxic heavy metals (cadmium, lead, etc.). Some of these elements, in small quantities, have a positive effect on plant development. However, with the systematic introduction of inflated standards, associated compounds accumulate in the soil in significant quantities. This negatively affects its properties and fertility, whereas their entry into groundwater increases mineralization.

Municipal solid waste landfills are a significant source of biological contamination, as they are a breeding ground for pathogenic microorganisms, providing favorable conditions for the development of helminth eggs. These hazardous biological components, together with dust and leachate, can spread far beyond landfills, significantly degrading the quality of natural waters and soil cover. According to environmental reports, more than 10 thousand tons of garbage have been accumulated in the Stryi drinking water intake in the Stryi river basin, only at officially registered landfills, which are ordinary landfills, and the largest places of solid waste are Stryi, Turka and Skole, as well as the Skhidnytsia and Slavske towns.

Despite these factors, significant pollution of surface waters in the Stryi river basin due to natural self-purification processes is not observed. All reservoirs are subject to natural selfpurification, in which pollution is broken down into simple compounds that enter the general biotic cycle. The most active processes of selfpurification take place in rivers in the presence of flow. With a stronger flow as well as considerable width and depth of the river, it copes better with pollution. Hydrodynamically active areas (HAA) of rivers have an important influence on increasing the efficiency of natural self-purification,

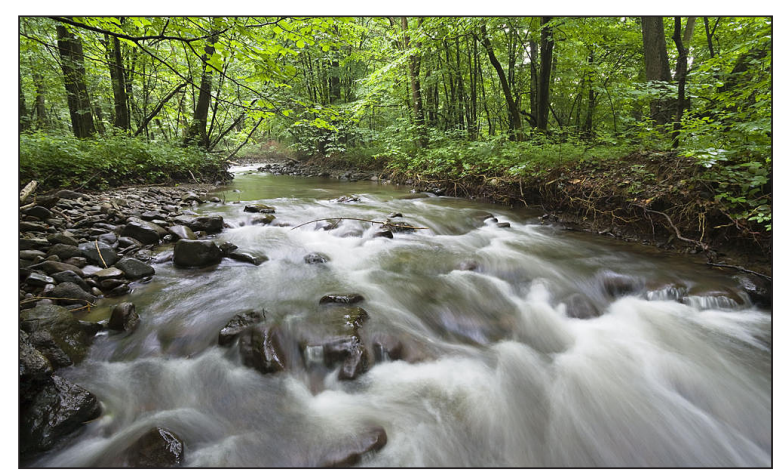

Figure 3. Hydrodynamically active area on the tributary of the Stryi River where the main oxygen enrichment of water flows takes place and biochemical and biological processes of river water self-purification are activated. HAA is a local natural or artificial obstacle in the course of a watercourse, namely a waterfall, boulders, gullies, rapids and their cascades (Fig. 3) [Borutska, 2015; Reid and Hickin, 2008; Snitynskyi et al., 2021].

According to the conditions of groundwater accumulation in the pores and fractured space of rocks and patterns of their movement, the basin of the Stryi River (Fig. 4) is located within two large hydrogeological areas, namely the hydrogeological area of the Eastern Carpathians and Precarpathian Artesian Basin, which have minimal man-made changes in groundwater quality.

Along the river Stryi, in the area from the village Rozgirche to the village Duliby, the aquifer of the Stryi groundwater deposit was formed. Currently, the field is operated by three coastal water intakes: Zhulynsky, Bratkivsky and Lyubynetsky. Water intake wells are located along the Stryi River, which under such conditions, is a conditionally unlimited supply circuit. The Lyubynetsky water intake provides water to the cities of Drohobych, Truskavets, Stebnyk,
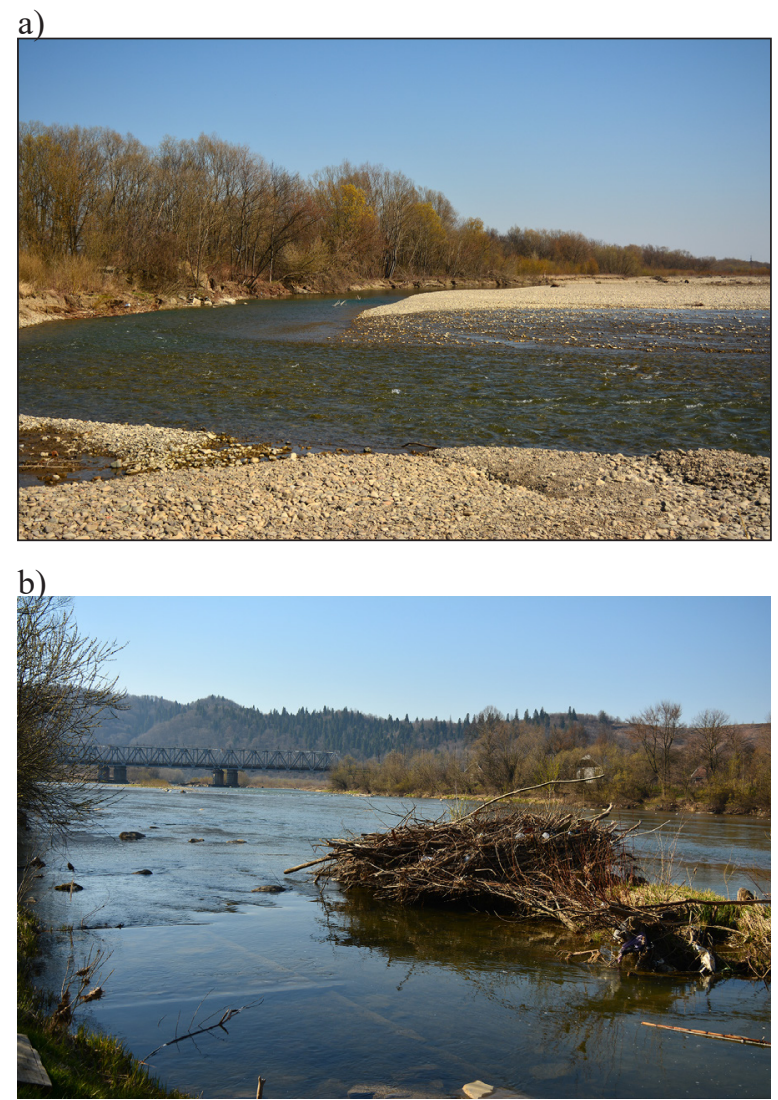

Figure 4. Stryi River near the village of Hirne (a) and the village of Mezhibrody (b) 
Boryslav, Zhulynsky - Lviv, and Bratkivsky Stryi and Morshyn. (Fig. 5).

The main indicators of drinking water of centralized water supply networks depend on the quality of water in the sources of drinking water supply of available water resources, technical level and compliance of water purification and distribution systems, the state of water mains, as well as the effectiveness of water protection measures. Quality control of tap drinking water in Ukraine is mainly carried out before it enters the distribution network.

In order to study the main indicators of drinking water quality of the Stryi water supply network, sampling for analysis was performed at all wells of the Stryi water intake for the period
2016-2019, and the generalized indicators were taken in clean water tanks (CWT) at the pumping station of the 2nd rise (village Bratkivtsi).

Determination of the hydrochemical composition of the selected samples was carried out in the laboratories for the study of drinking water and analysis of wastewater treatment plants Municipal Enterprise "Stryivodokal" on the basis of relevant regulations in Ukraine [Snitynskyi et al., 2020]. The results of these studies are shown in Fig. 6-12.

Laboratory studies of the main indicators of artesian water in the wells of the Stryi water intake for 2016-2020 years allowed drawing the following conclusions:

1. At the artesian well № 24 in 2016 there was a slight increase in the $\mathrm{pH}$ of drinking water

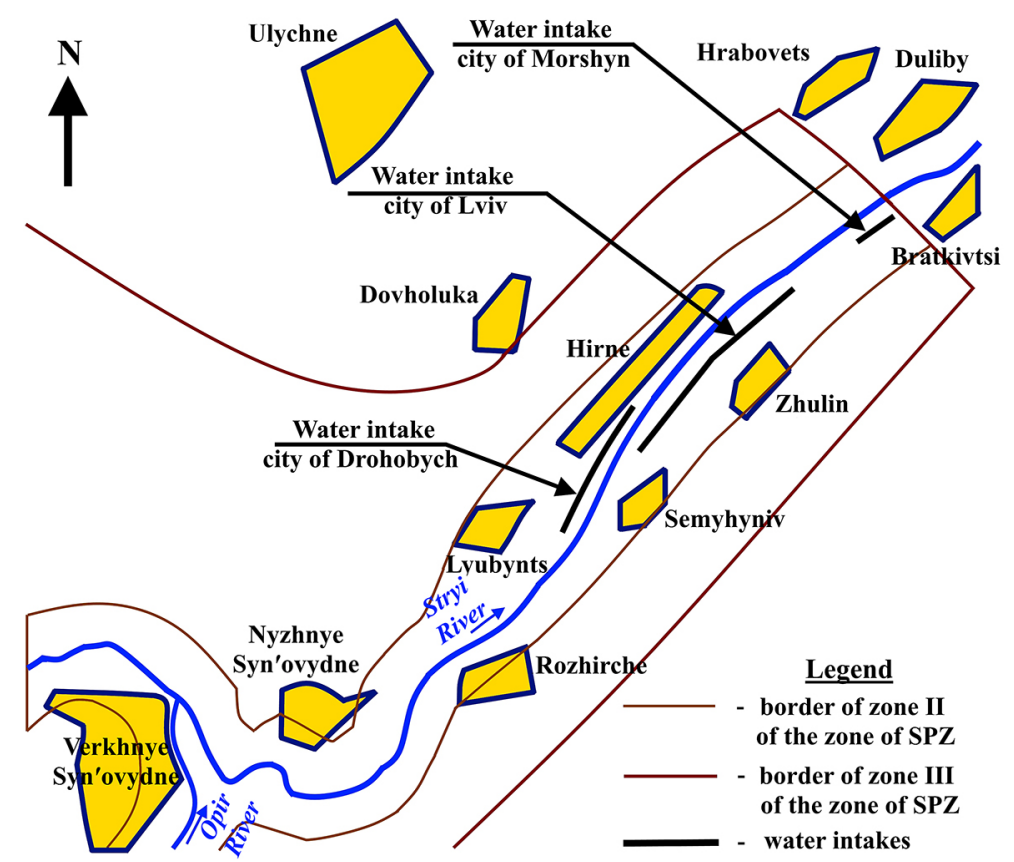

Figure 5. Location of water intakes of the groundwater deposit on the river Stryi [Hnativ, 2021]

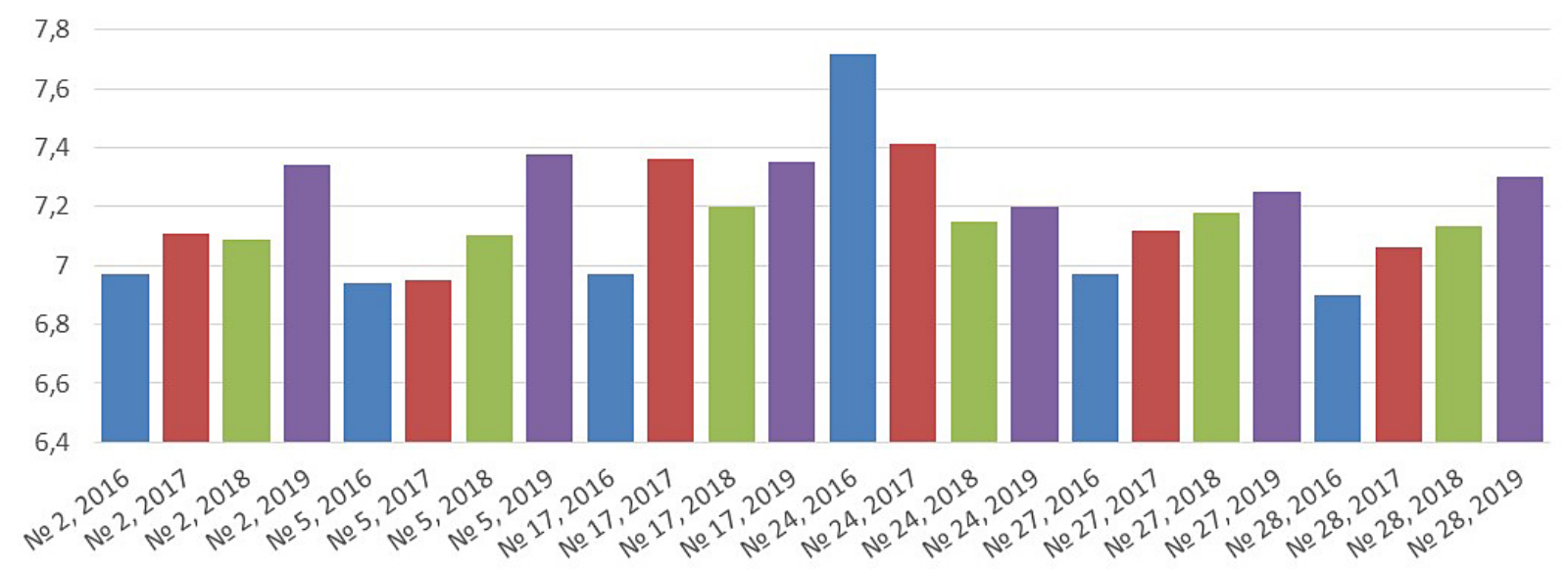

Figure 6. The $\mathrm{pH}$ indicators of drinking water from the wells of the Stryi water intake for 2016-2020 


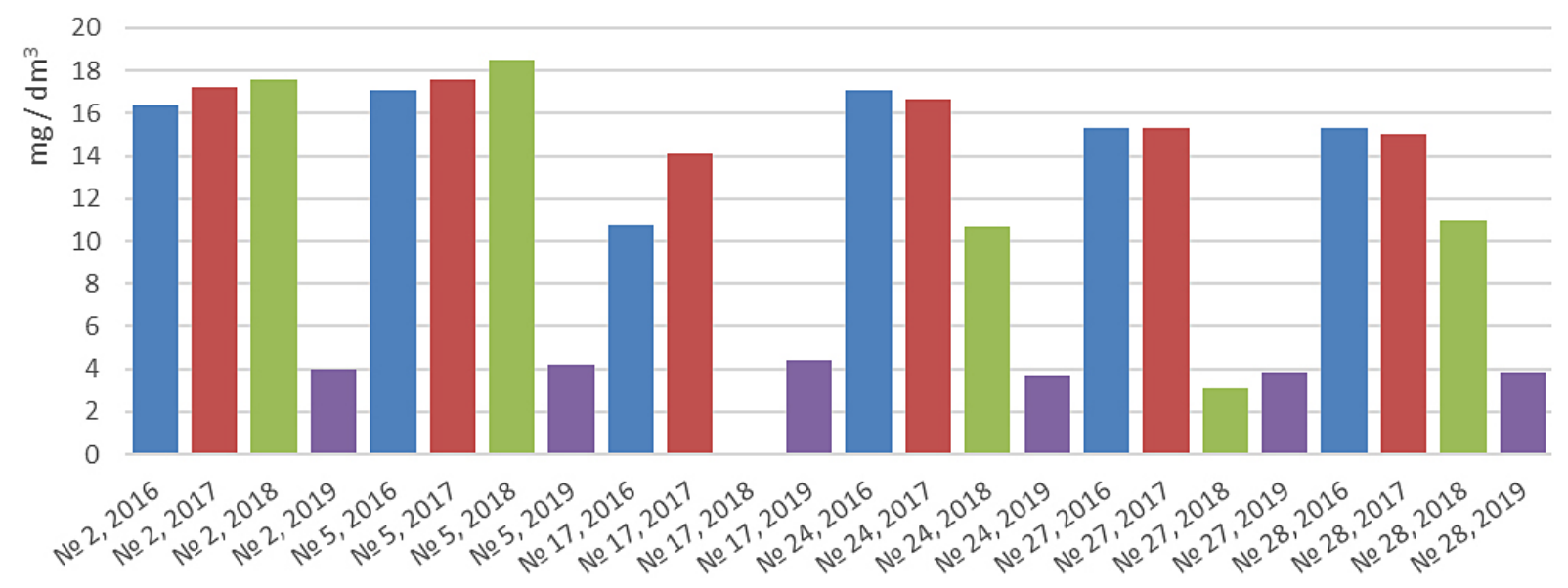

Figure 7. Content of nitrates (nitrate nitrogen) of drinking water of water intake wells for 2016-2020

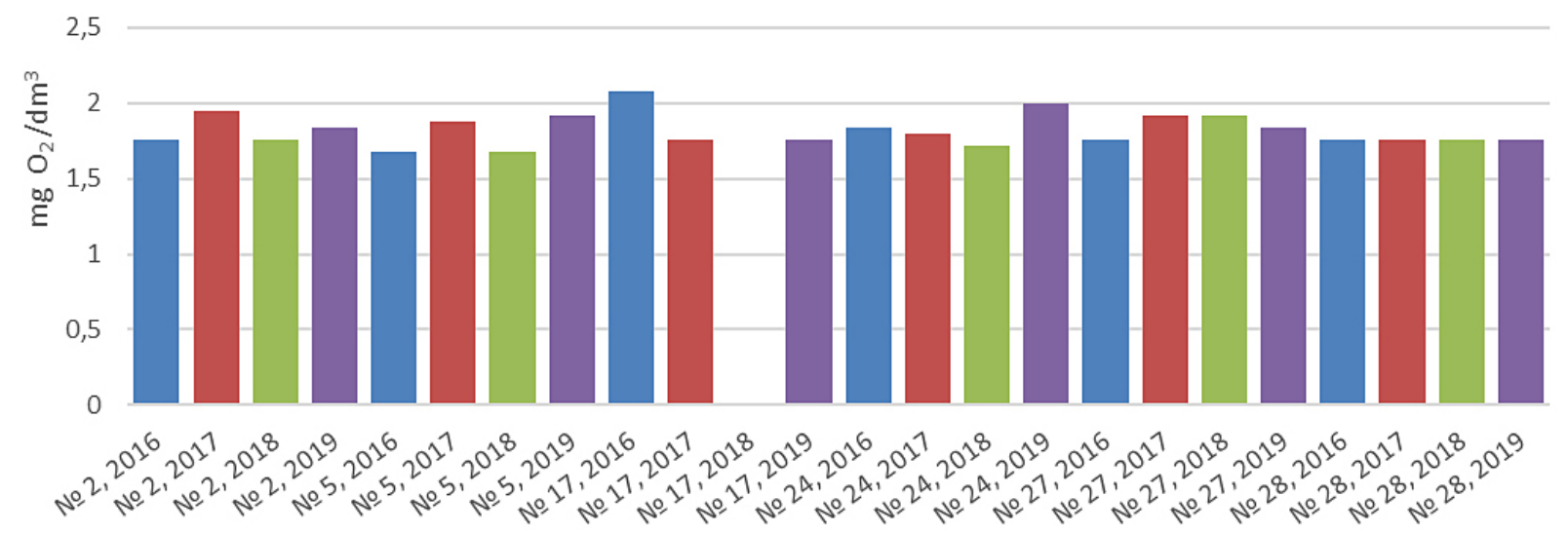

Figure 8. The value of dissolved oxygen in drinking water wells for 2016-2020

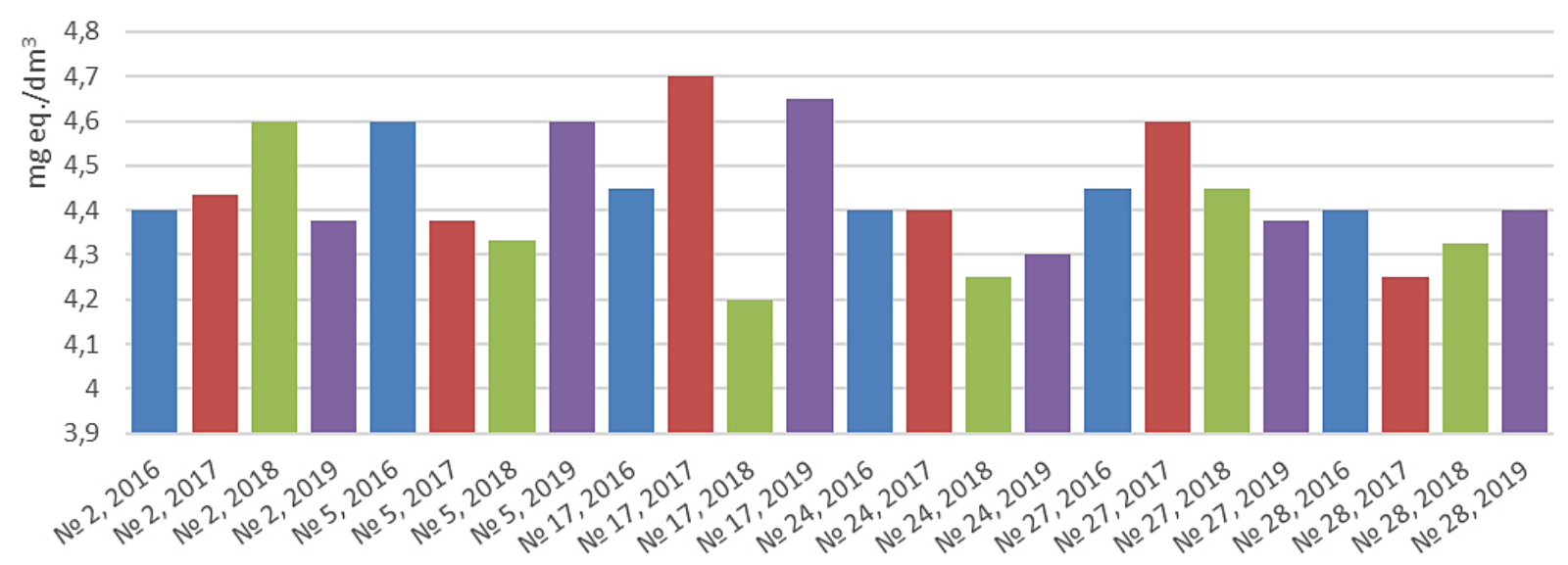

Figure 9. Change in the total hardness of drinking water in wells for 2016-2020

relative to other wells, but in 2017-2020 its value decreased and became commensurate with other wells (Fig. 6).

2. The $\mathrm{pH}$ values of all water intake wells during the study period did not exceed the MPC for drinking water according to DSanPin 2.2.4-171-10.

3 . The nitrate content of artesian water in wells for 2019-2020 years significantly decreased, which is explained by the improvement of compliance with the requirements of the water protection zone of the Stryi water intake (Fig. 7).

4. Analysis of drinking water from artesian wells in the water supply system of the city of Stryi shows its high quality and lack of negative impact of river water on the groundwater deposit of the Bratkivsky water intake. 


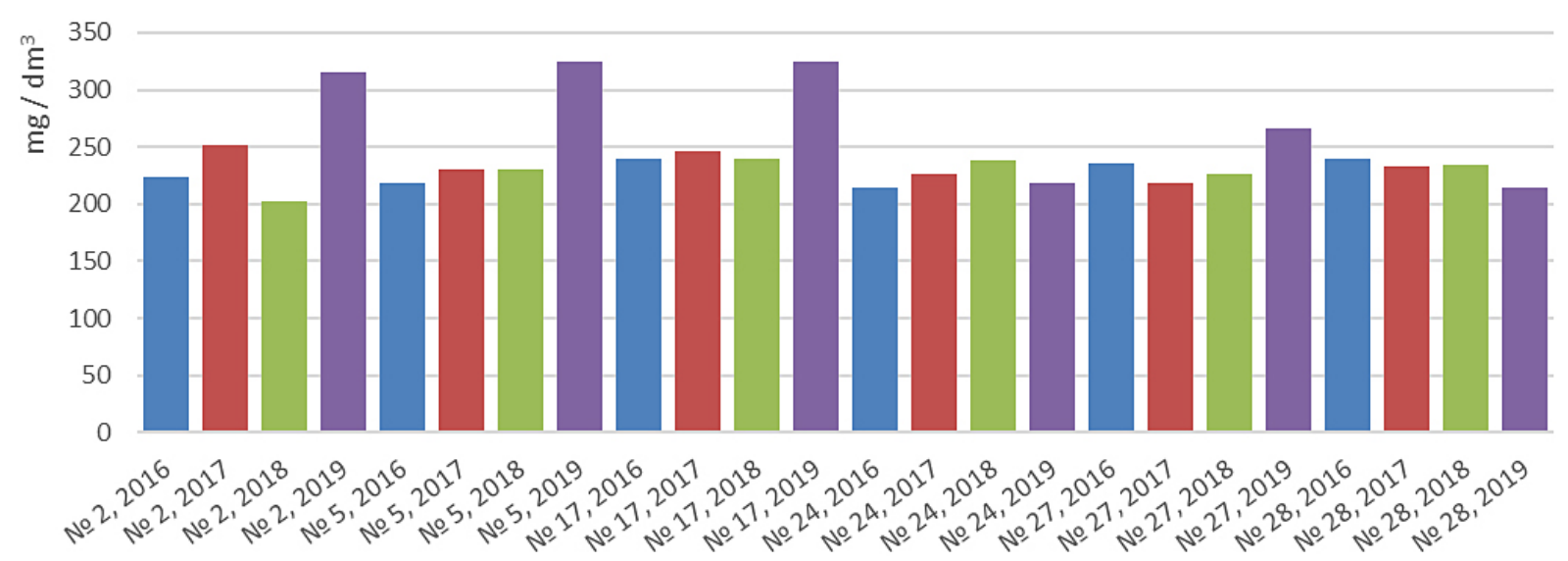

Figure 10. The value of the dry residue of drinking water intake for 2016-2020

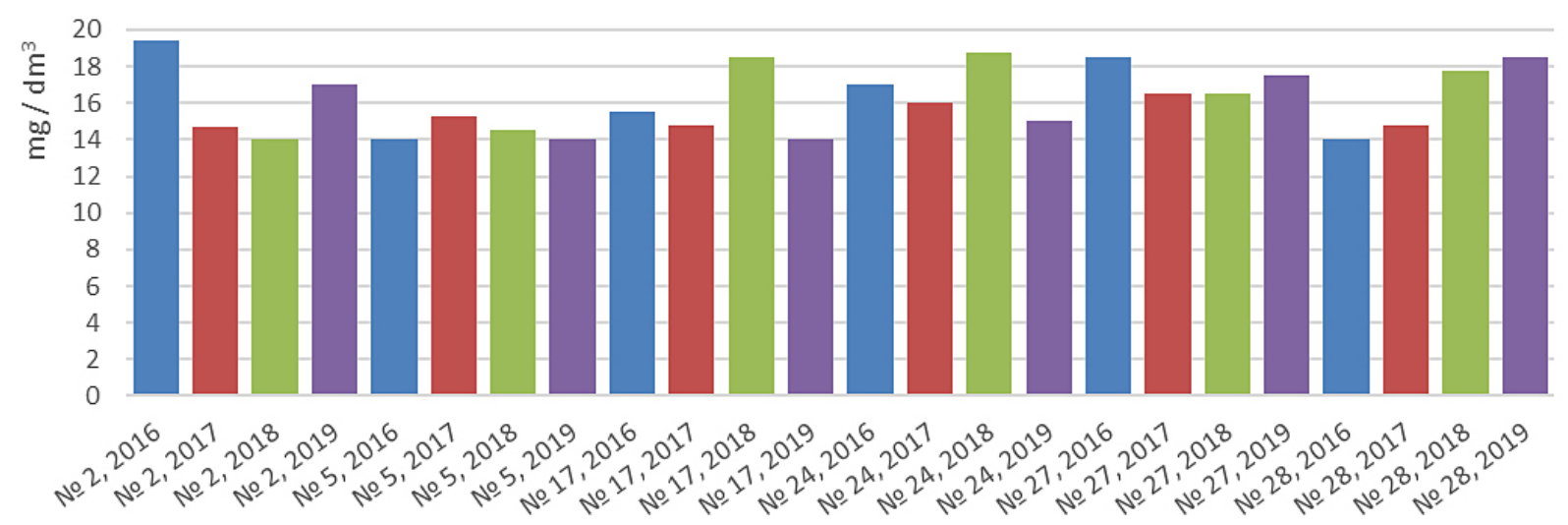

Figure 11. Chloride content in drinking water of water intake wells for 2016-2020

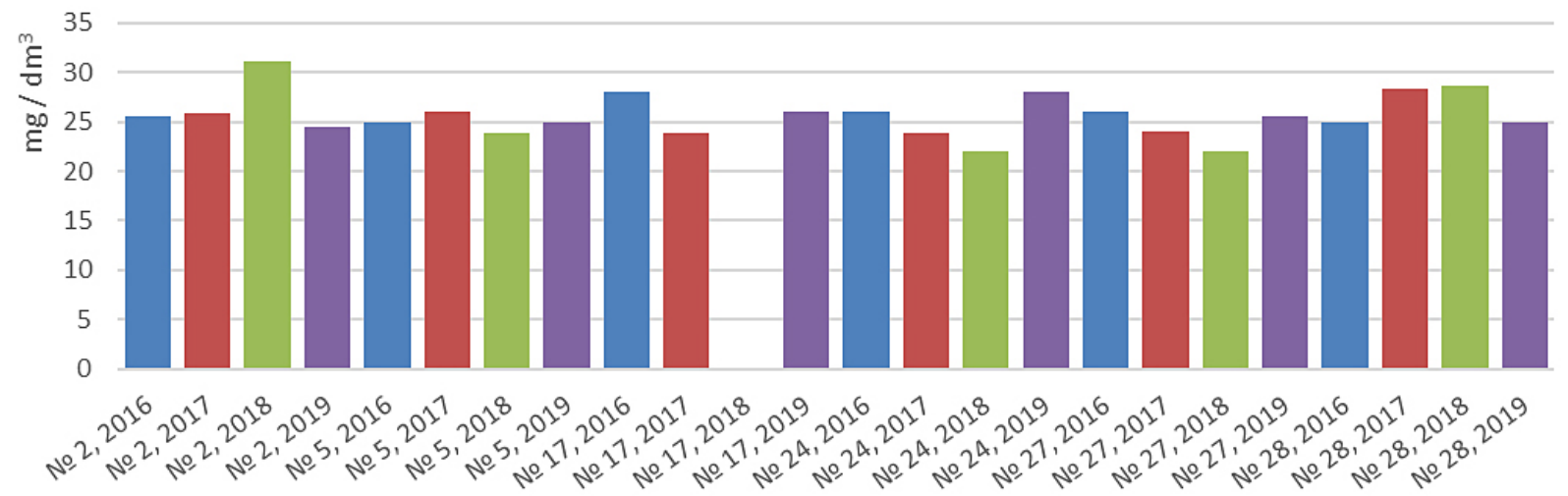

Figure 12. Values of sulfate content in drinking water from the wells of the Stryi water intake for 2016-2020

5. The total hardness of drinking water in wells is in the range of $4.2-4.8 \mathrm{mg}$ eq. $/ \mathrm{dm}^{3}$ (Fig. 9).

6 . The value of the dry residue of the Stryi water intake is $202-250 \mathrm{mg} / \mathrm{dm}^{3}$, but in $2019-2020$ in some wells they increased to $316-324 \mathrm{mg} / \mathrm{dm}^{3}$, according to the MPC $\leq 1000 \mathrm{mg} / \mathrm{dm}^{3}$ (Fig. 10).

7. The content of chlorides and sulfates in water varies between $14.0-19.4 \mathrm{mg} / \mathrm{dm}^{3}$ and 22.0 $31.2 \mathrm{mg} / \mathrm{dm}^{3}$, respectively, with an MPC $\leq 250$ $\mathrm{mg} / \mathrm{dm}^{3}$ (Figs. 11, 12).

\section{CONCLUSIONS}

The results of studies related to the impact of self-cleaning processes in the river Stryi on the quality of water intake in the city of Stryi showed that the drinking water from artesian wells is of high quality and there are no negative effects of river water in the Stryi river basin. The quality of river water is satisfactory for its use in domestic and drinking water supply and for recreational purposes. 


\section{REFERENCES}

1. Didula R.P., Kondratyuk E.I., Blavatsky Y.B. et al. 2018. Assessment of sanitary-chemical indicators of water safety and quality of popular sources of different geostructural zones of Lviv region. Hydrology, hydrochemistry and hydroecology, 4(51), 87-101. (in Ukrainian)

2. Prokopov V.O., Zorina O.V., Protas S.V., Lyashko V.K. 2011. Changes and additions to DSanPin 2.2.4-171-10. Hygienic requirements for human consumption - a way to improve the regulatory document. Hygiene of human settlements, 58, 71-77. (in Ukrainian)

3. Prodanchuk M.G., Mudryy I.V., Velykyi V.I. 2006. Scientific and methodological aspects of toxicological and clinical studies of the impact of mineral composition of drinking water on the health of the population of Ukraine (literature review). Modern problems of toxicology, 3, 4-7. (in Ukrainian)

4. Hnativ I.R. 2021. Influence of anthropogenic factors on the quality of drinking water in the wells of the Stryi water intake. Scientific and practical journal «Environmental Sciences», 2(35), 25-29. (in Ukrainian)

5. Ivanov E. 2009. Geocadastral research of mining territories: Monograph. Lviv: Ivan Franko Lviv National University Publishing Center, 372. (in Ukrainian)
6. Hrib O.M., Belov V.V., Otchenash N.D. 2015. Assessment, forecasting and quality management of water resources: Lecture notes. Odessa: ODEKU, 121. (in Ukrainian)

7. National report on drinking water quality and the state of drinking water supply in Ukraine in 2019. SE «NDKTI MG», Kyiv 2020, 353. https:/www. minregion.gov.ua/wp-content/uploads/ 2020/12/ naczionalna-dopovid-za-2019-rik.pdf(in Ukrainian)

8. Radecki-Pawlik A., Pagliara S., Hradecky J. 2018. Open Channel Hydraulics, River Hydraulic Structures and Fluvial Geomorphology. Publisher: CRC, Taylor \& Francis, 516.

9. Borutska Y.Z. 2015. Cavitation and aeration impact of hydrodynamic barriers on the quality of natural waters of the Stryi river basin. Scientific notes of TNPU. Series: Biology, 3-4(64), 66-69. (in Ukrainian)

10. Reid D.E., Hickin E.J. 2008. Flow resistance in steep mountain streams. Earth Surface Processes and Landforms, 33, 2211-2240.

11. Snitynskyi V., Khirivskyi P., Hnativ I., Yakhno O., Machuga O., Hnativ R. 2021. Visualization of River Water Flow in Hydrodynamically Active Areas under Different Flow Regimes. Journal of Ecological Engineering, 22(9), 130-136.

12. Snitynskyi V.V., Khirivskyi P.R., Hnativ I.R. 2020. The impact of the urban area of the city of Stryi on the quality of river water. Bulletin of LNAU: agronomy, 24, 17-22. (in Ukrainian) 